\title{
ARTICLE
}

\section{Stability of Ciprofloxacin in Polyvinylchloride Minibags}

\author{
Ronald F Donnelly
}

\begin{abstract}
Background: Ciprofloxacin is a fluoroquinolone antibiotic used to treat infections caused by both gram-positive and gram-negative organisms.
\end{abstract}

Objective: To determine the physical and chemical stability of ciprofloxacin diluted in $5 \%$ dextrose in water (D5W) or $0.9 \%$ sodium chloride (normal saline [NS]) and stored in polyvinylchloride (PVC) minibags at various temperatures.

Methods: Solutions of ciprofloxacin ( 1 and $2 \mathrm{mg} / \mathrm{mL}$ ) were prepared by diluting a commercially available concentrate $(10 \mathrm{mg} / \mathrm{mL})$ with either D5W or NS. The prepared solutions were then packaged in PVC minibags. Three minibags of each concentration-diluent combination were stored at $2^{\circ} \mathrm{C}$ to $8^{\circ} \mathrm{C}$ with protection from light, at $21^{\circ} \mathrm{C}$ to $24^{\circ} \mathrm{C}$ with exposure to light, and at $29^{\circ} \mathrm{C}$ to $31^{\circ} \mathrm{C}$ with protection from light. Samples were collected from each minibag on days 0, 7, 14, and 30 and then analyzed. Colour, clarity, and $\mathrm{pH}$ were monitored when the samples were collected. On each day of analysis, the samples were accurately diluted before duplicate analysis with a stability-indicating high-performance liquid chromatography assay. A solution was considered stable if the concentration remained above $90 \%$ of the initial values.

Results: There were no changes in the physical characteristics of any of the solutions. At both concentrations ( 1 and $2 \mathrm{mg} / \mathrm{mL}$ ), the ciprofloxacin solutions prepared in D5W remained above $93.9 \%$ of the initial concentration over the 30-day study period under all 3 storage conditions. Similarly, at both concentrations, solutions diluted in NS remained above $95.9 \%$ of the initial concentration over the 30-day study period under all 3 storage conditions.

Conclusions: Ciprofloxacin prepared in either D5W or NS and stored in PVC minibags was stable for 30 days under 3 separate storage conditions: $2^{\circ} \mathrm{C}$ to $8^{\circ} \mathrm{C}$ with protection from light, $21^{\circ} \mathrm{C}$ to $24^{\circ} \mathrm{C}$ with exposure to light, and $29^{\circ} \mathrm{C}$ to $31^{\circ} \mathrm{C}$ with protection from light.

Key words: ciprofloxacin, injection, dextrose, normal saline, stability, high-performance liquid chromatography, polyvinylchloride minibags

Can J Hosp Pharm 2011;64(4):252-256

\section{RÉSUMÉ}

Contexte : La ciprofloxacine est un antibiotique de la famille des fluoroquinolones utilisé dans le traitement des infections à bactéries Gram-positif et Gram-négatif.

Objectif : Déterminer la stabilité physique et chimique de la ciprofloxacine diluée dans du dextrose à $5 \%$ dans l'eau (D5E) ou dans du chlorure de sodium à $0,9 \%$ (solution physiologique salée [SP]) conditionnée dans des minisacs de polychlorure de vinyle (PVC) entreposés à diverses températures.

Méthodes : Les solutions de ciprofloxacine (concentrations de 1 et de 2 $\mathrm{mg} / \mathrm{mL}$ ) ont été préparées en diluant une préparation concentrée commercialisée $(10 \mathrm{mg} / \mathrm{mL})$ dans du D5E ou de la SP. Les solutions ainsi préparées ont été conditionnées dans des minisacs de PVC. Trois minisacs de chaque combinaison de concentration et de diluant ont été entreposés à une température de $2{ }^{\circ} \mathrm{C}$ à $8{ }^{\circ} \mathrm{C}$, à l'abri de la lumière; de $21^{\circ} \mathrm{C}$ à $24^{\circ} \mathrm{C}$, exposés à la lumière; et de $29^{\circ} \mathrm{C}$ à $31^{\circ} \mathrm{C}$, à l'abri de la lumière. Des échantillons ont été prélevés de chaque minisac aux jours $0,7,14$ et 30, puis analysés. La couleur, la limpidité et le $\mathrm{pH}$ ont été contrôlés lors du prélèvement des échantillons. Les jours d'analyse, les échantillons ont été dilués de façon précise avant qu'ils ne soient soumis à un double dosage au moyen d'une épreuve de stabilité par chromatographie liquide à haute pression. Une solution était jugée stable si la concentration se maintenait à plus de $90 \%$ des valeurs initiales.

Résultats : Aucun changement dans les caractéristiques physiques n’a été observé dans l'une ou l'autre des solutions. Pour les deux concentrations (1 et $2 \mathrm{mg} / \mathrm{mL}$ ), les solutions de ciprofloxacine préparées dans du D5E ont conservé plus de $93,9 \%$ de la concentration initiale pendant 30 jours dans les trois conditions d'entreposage. De même, pour les deux concentrations, les solutions diluées dans de la SP ont conservé plus de $95,9 \%$ de la concentration initiale pendant 30 jours dans les trois conditions d'entreposage.

Conclusions : Les solutions de ciprofloxacine préparées dans du D5E ou de la SP sont demeurées stables pendant 30 jours lorsqu'elles étaient conservées dans des minisacs de PVC à une température de $2{ }^{\circ} \mathrm{C}$ à $8{ }^{\circ} \mathrm{C}$ ou de $29^{\circ} \mathrm{C}$ à $31^{\circ} \mathrm{C}$ et à l'abri de la lumière, ou à une température de $21^{\circ} \mathrm{C}$ à $24^{\circ} \mathrm{C}$, exposées à la lumière.

Mots clés : ciprofloxacine, injection, dextrose, solution physiologique salée, stabilité, chromatographie liquide haute performance, minisacs de polychlorure de vinyle

[Traduction par l'éditeur] 


\section{INTRODUCTION}

Ciprofloxacin is a fluoroquinolone antibiotic used to treat infections caused by both gram-positive and gramnegative organisms. Its mechanism of action is interference with DNA replication, transcription, repair, and recombination. The IV form is generally used to treat life-threatening infections.

The stability of several concentrations of ciprofloxacin has been studied in various brands of elastomeric reservoirs. ${ }^{1}$ Solutions were stable for 14 days at either room temperature or under refrigeration when diluted with either $5 \%$ dextrose in water (D5W) or $0.9 \%$ sodium chloride (normal saline [NS]). In another study, exposure to natural light caused a $9 \%$ decrease in concentration after $96 \mathrm{h.}^{2}$ Teraoka and others ${ }^{3}$ reported a substantial loss of concentration when the $\mathrm{pH}$ of the solution increased above 6 . There was no loss due to sorption when solutions of ciprofloxacin in NS (200 mg in $250 \mathrm{~mL}$ ) were infused through polyvinylchloride (PVC) administration sets. ${ }^{4}$ One manufacturer of prefilled minibags of ciprofloxacin has stated that the minibags should be stored at $25^{\circ} \mathrm{C}$ and are stable, within the overwrap, until the imprinted expiry date. Once the outer wrap is removed, the $100-\mathrm{mL}$ bags have a $14-$ day expiry period and the $200-\mathrm{mL}$ bags have a 30 -day expiry period if stored at $25^{\circ} \mathrm{C}$ with protection from light (Hospira Clinical Support Team, Hospira Healthcare Corp, SaintLaurent, Quebec; personal communication by letter, June 9, 2011).

This study was undertaken to provide physical compatibility and chemical stability data for ciprofloxacin solutions prepared by diluting a commercial concentrate with either D5W or NS to a concentration of 1.0 or $2.0 \mathrm{mg} / \mathrm{mL}$, followed by packaging in PVC bags and storage under a variety of temperatures and light conditions. This information could help to reduce wastage by allowing smaller centres to prepare and store single doses in advance (by diluting vial contents) or by allowing preparation of solutions in NS when commercial D5W solution cannot be used.

\section{METHODS}

\section{Sample Preparation}

Solutions were prepared by diluting, to either $1 \mathrm{mg} / \mathrm{mL}$ or $2 \mathrm{mg} / \mathrm{mL}$ with D5W or NS, ciprofloxacin hydrochloride (Sandoz; lot 140556, expiry June 2009, and lot 1397714, expiry May 2009) before packaging in PVC minibags. A total of thirty-six 100-mL PVC bags were prepared. Three bags of each concentration-diluent combination were then stored at each of 3 temperatures: $2^{\circ} \mathrm{C}$ to $8^{\circ} \mathrm{C}$ (refrigeration) with protection from light, $21^{\circ} \mathrm{C}$ to $24^{\circ} \mathrm{C}$ (room temperature) with exposure to light, and $29^{\circ} \mathrm{C}$ to $31^{\circ} \mathrm{C}$ (incubator) with protection from light.

\section{Physical Compatibility}

Immediately after sample collection, as described below, each solution was inspected for clarity against a black background and for colour change against a white background using a $4 \times$ illuminated magnifying glass. The $\mathrm{pH}$ was determined on each day of analysis using a calibrated $\mathrm{pH}$ meter (Accumet 25, Fisher Scientific Ltd, Nepean, Ontario). The $\mathrm{pH}$ meter was calibrated before each set of determinations with buffers ( $\mathrm{pH} 4$ [Fisher Scientific Ltd, lot SC6236793, expiry September 30, 2008] and $\mathrm{pH} 7$ [Fisher Scientific Ltd, lot SC7134746, expiry May 31, 2009]).

\section{Stability Study}

Immediately after packaging, one $5-\mathrm{mL}$ sample was removed from each bag and placed into a clean glass test tube. These samples were designated as day 0 samples and were analyzed on the day of collection. Subsequently, on days 7, 14, and 30, similar samples were collected and then analyzed.

On each day of analysis, the solutions were diluted with acetonitrile (at a ratio of $1: 20$ for $1 \mathrm{mg} / \mathrm{mL}$ solutions or $1: 40$ for $2 \mathrm{mg} / \mathrm{mL}$ solutions) and then assayed, as described below.

\section{High-Performance Liquid Chromatography Chromatographic System}

The mobile phase used for analysis, as described for ciprofloxacin hydrochloride in the United States Pharmacopeia, 30th edition, ${ }^{5}$ contained $13 \%$ acetonitrile and $87 \%$ phosphoric acid $0.025 \mathrm{~mol} / \mathrm{L}$. The $\mathrm{pH}$ of the final mixture was adjusted to $\mathrm{pH} 3.0 \pm 0.1$ with triethylamine. The solid phase was a Luna C18 5- $\mu \mathrm{m}, 4.6 \times 150 \mathrm{~mm}$ column (Phenomenex Inc, Torrance California, lot 268955-36). The flow rate of $1 \mathrm{~mL} / \mathrm{min}$ was delivered with an isocratic delivery pump (model LC-10ATvip, Shimadzu Scientific Instruments Inc, Columbia, Maryland). The peaks were monitored at $278 \mathrm{~nm}$ with a photodiode array detector (model SPD-M6A, Shimadzu Scientific Instruments Inc). Each $50-\mu \mathrm{L}$ injection volume was placed onto the column by means of an autoinjector (model Sil-10A $\mathrm{xL}_{\text {, Shimadzu }}$ Scientific Instruments Inc). Data were collected and analyzed with Class-VP software (version 4.2, Shimadzu Scientific Instruments Inc).

\section{Assay Validation}

The specificity of the assay method was determined by analyzing forced degradation samples. A $10-\mathrm{mL}$ sample of a stock solution of ciprofloxacin $\mathrm{HCl}$ (Sandoz, $10 \mathrm{mg} / \mathrm{mL}$, lot 139771, expiry May 2009) was adjusted to about $\mathrm{pH} 1.20$ with concentrated hydrochloric acid (BDH, Toronto, ON; lot 120834-78180). A second degradation sample was prepared by adjusting the $\mathrm{pH}$ of a $10-\mathrm{mL}$ sample of stock solution to about 
5.0 with sodium hydroxide $1 \mathrm{~N}$ and $0.1 \mathrm{~N}$ (Fisher Scientific Ltd; lot SC625970, expiry September 30, 2008, and lot SC188376, expiry July 31, 2007, respectively). To prepare an oxidized degradation sample, $0.5 \mathrm{~mL}$ of $30 \%$ hydrogen peroxide (Fisher Scientific Ltd; lot 043211) was combined with $9.5 \mathrm{~mL}$ of the stock solution. Finally, $10 \mathrm{~mL}$ of ciprofloxacin stock solution was placed into a glass test tube, which was sealed with a rubber stopper and placed under an ultraviolet (UV) lamp that generated short-wavelength light. At time zero, $10 \mu \mathrm{L}$ of ciprofloxacin stock solution was diluted with $990 \mu \mathrm{L}$ of mobile phase and analyzed. The acidic and $\mathrm{pH} 5$ samples were incubated at $50^{\circ} \mathrm{C}$ in a hot water bath, whereas the oxidized sample and the sample exposed to UV light were stored at $23^{\circ} \mathrm{C}$. At 2, 22, 95, 118, 142, 166, 190, 262, and $286 \mathrm{~h}$, samples were collected from all degradation samples, diluted 1 in 100 with mobile phase, and analyzed. In addition, ciprofloxacin ethylenediamine analogue (United States Pharmacopeia, Bethesda, Maryland; catalogue no. 13432, lot JOA030) was analyzed for interference with the parent peak.

Multiwavelength (260 and $278 \mathrm{~nm}$ ) and UV spectral analyses $(200-350 \mathrm{~nm})$ were used to determine the purity of the ciprofloxacin peaks. Correlation coefficients of the UV spectra were determined by comparing the ciprofloxacin peaks from the degradation samples with ciprofloxacin $\mathrm{HCl}$ reference material (United States Pharmacopeia; catalogue no. 1134335 , lot IOC265).

The linearity of all standard curves was assessed using least-squares regression analysis. The average area of 5 replicate injections at 3 separate time periods was used to measure the intraday variation and was reported as the coefficient of variation $(\mathrm{CV})$. The slopes, linear coefficients, and average areas from 5 separate days were used to determine the interday variation of the method. The average of 3 sets of recovery samples, analyzed in duplicate, from 5 separate days was used to measure the accuracy of the method. The sensitivity of the assay was also determined.

\section{RESULTS}

\section{Physical Compatibility Study}

There was no appearance of precipitate when samples were observed under $4 \times$ magnification. The samples took on a slight yellow colour at time zero, but the colour did not intensify over the course of the study. The $\mathrm{pH}$ did not change over the 30-day period (range 3.85 to 3.62 ).

\section{Chemical Stability Study Assay Validation}

Heating of the acidic degradation sample resulted in a decrease in concentration to about $85 \%$ after $286 \mathrm{~h}$ of exposure (Figure 1a). Exposure of ciprofloxacin to a higher $\mathrm{pH}$ with

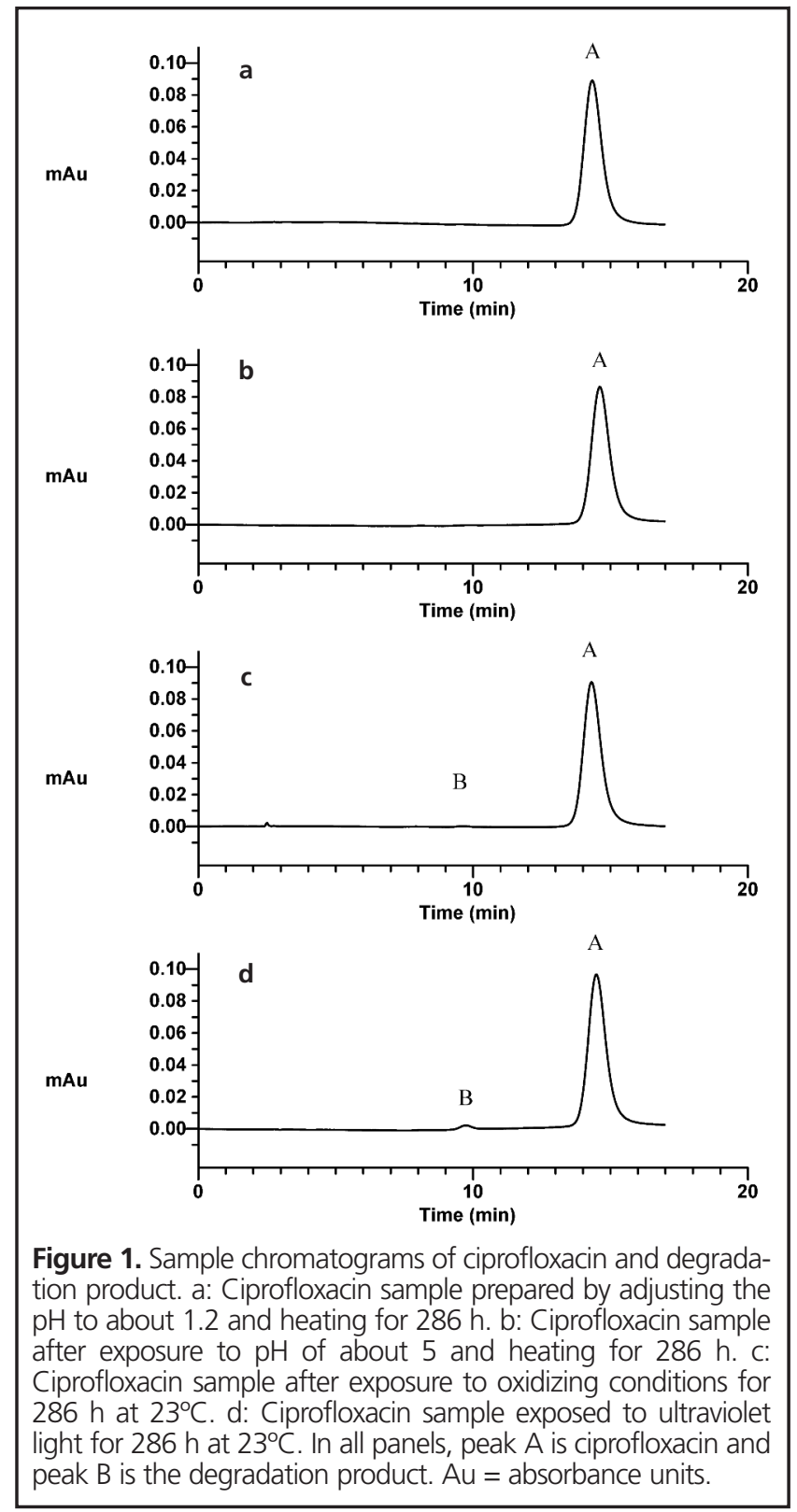

heating in the second degradation sample caused reduction in concentration by about 20\% (Figure 1b). Oxidation and exposure to UV light had similar effects on the ciprofloxacin, reducing the concentration to $89 \%$ of the original (Figure 1c and 1d). There was no interference with the peak of the parent compound from any of the degradation peaks or the ciprofloxacin ethylenediamine analogue. The purity of all parent peaks from the degradation samples was confirmed by multichannel and UV spectral analysis. Comparison of the spectra of the parent compound from the degradation samples with the reference material resulted in correlation greater than 0.990 .

The intraday CV was $0.27 \%$ based on comparison of area ratios determined at 0,11 , and $24 \mathrm{~h}$. The interday $\mathrm{CVs}$ were $1.62 \%, 0.02 \%$, and $1.09 \%$ for comparisons of slopes, linear 
coefficients, and average areas, respectively, from 5 separate days. The average recovery from samples of known concentration was $99.3 \% \pm 0.71 \%$. The sensitivity of the assay was determined to be $5.0 \mathrm{ng}$ ciprofloxacin.

\section{Stability Study}

The results for determination of chemical stability of ciprofloxacin are summarized in Tables 1 and 2. Ciprofloxacin prepared in either D5W (Table 1) or NS (Table 2) and packaged in PVC bags was stable for 30 days under 3 sets of storage conditions: $2^{\circ} \mathrm{C}$ to $8^{\circ} \mathrm{C}$ with protection from light, $21^{\circ} \mathrm{C}$ to $24^{\circ} \mathrm{C}$ with exposure to light, and $29^{\circ} \mathrm{C}$ to $31^{\circ} \mathrm{C}$ with protection from light.

\section{DISCUSSION}

Mathew and others ${ }^{6}$ studied the stability of ciprofloxacin for injection (Miles) (about $3 \mathrm{mg} / \mathrm{mL}$ ) diluted in either D5W or NS and found the solutions to be stable in PVC bags for 90 days when stored at either $5^{\circ} \mathrm{C}$ or $25^{\circ} \mathrm{C}$. The manufacturer of generic ciprofloxacin $10 \mathrm{mg} / \mathrm{mL}$ (Sandoz) recommends that 1 and $2 \mathrm{mg} / \mathrm{mL}$ solutions prepared in D5W or NS be used within 24 at room temperature or $72 \mathrm{~h}$ when refrigerated and protected from light. ${ }^{7}$ Tiefenbacher and others ${ }^{2}$ found that solutions of ciprofloxacin exposed to UVA light showed signs of photodegradation, with $2 \%$ degradation after $12 \mathrm{~h}$ of exposure and $9 \%$ reduction after $96 \mathrm{~h}$.

Table 1. Stability of Ciprofloxacin in 5\% Dextrose in Water in Polyvinylchloride Bags

Storage Temperature;

$\%$ of Initial Concentration Remaining ${ }^{*} \dagger$

\begin{tabular}{|c|c|c|c|}
\hline Study Day & $2^{\circ} \mathrm{C}$ to $8^{\circ} \mathrm{C} \mp$ & $21^{\circ} \mathrm{C}$ to $24^{\circ} \mathrm{C} \S$ & $29^{\circ} \mathrm{C}$ to $31^{\circ} \mathrm{C} \ddagger$ \\
\hline \multicolumn{4}{|l|}{$1 \mathrm{mg} / \mathrm{mL}$ solution } \\
\hline Initial concentration (measured) $†$ & $1.0 \pm 0.01$ & $1.0 \pm 0.01$ & $1.0 \pm 0.02$ \\
\hline Day 7 & $93.9 \pm 0.6$ & $97.2 \pm 1.1$ & $95.2 \pm 1.3$ \\
\hline Day 14 & $96.2 \pm 1.3$ & $95.9 \pm 2.4$ & $96.7 \pm 0.9$ \\
\hline Day 30 & $96.8 \pm 1.6$ & $98.4 \pm 1.5$ & $99.9 \pm 1.1$ \\
\hline \multicolumn{4}{|l|}{$2 \mathrm{mg} / \mathrm{mL}$ solution } \\
\hline Initial concentration (measured) $†$ & $2.0 \pm 0.01$ & $2.0 \pm 0.01$ & $2.0 \pm 0.02$ \\
\hline Day 7 & $95.2 \pm 0.4$ & $97.8 \pm 1.4$ & $96.7 \pm 0.4$ \\
\hline Day 14 & $97.1 \pm 1.0$ & $100.0 \pm 0.9$ & $95.5 \pm 1.7$ \\
\hline Day 30 & $96.9 \pm 1.7$ & $97.3 \pm 1.7$ & $99.1 \pm 1.3$ \\
\hline
\end{tabular}

$\mathrm{SD}=$ standard deviation.

*Except as indicated otherwise.

†Mean \pm SD $(n=6)$.

$\neq$ With protection from light.

$\S$ With exposure to light.

Table 2. Stability of Ciprofloxacin in $\mathbf{0 . 9 \%}$ Sodium Chloride (Normal Saline) in Polyvinylchloride Bags

Storage Temperature;

$\%$ of Initial Concentration Remaining ${ }^{*} \dagger$

\begin{tabular}{|c|c|c|c|}
\hline Study Day & $2^{\circ} \mathrm{C}$ to $8^{\circ} \mathrm{C} \ddagger$ & $21^{\circ} \mathrm{C}$ to $24^{\circ} \mathrm{C} \S$ & $29^{\circ} \mathrm{C}$ to $31^{\circ} \mathrm{C} \neq$ \\
\hline \multicolumn{4}{|l|}{$1 \mathrm{mg} / \mathrm{mL}$ solution } \\
\hline Initial concentration (measured) $†$ & $1.0 \pm 0.01$ & $1.0 \pm 0.02$ & $1.0 \pm 0.02$ \\
\hline Day 7 & $100.6 \pm 1.0$ & $99.5 \pm 0.8$ & $100.6 \pm 1.1$ \\
\hline Day 14 & $99.9 \pm 1.2$ & $97.6 \pm 0.8$ & $101.2 \pm 1.4$ \\
\hline Day 30 & $102.4 \pm 0.9$ & $101.8 \pm 1.5$ & $104.1 \pm 1.3$ \\
\hline \multicolumn{4}{|l|}{$2 \mathrm{mg} / \mathrm{mL}$ solution } \\
\hline Initial concentration (measured) $\dagger$ & $2.0 \pm 0.03$ & $2.0 \pm 0.02$ & $2.0 \pm 0.01$ \\
\hline Day 7 & $96.9 \pm 1.1$ & $99.2 \pm 1.1$ & $96.3 \pm 0.8$ \\
\hline Day 14 & $97.3 \pm 1.6$ & $101.4 \pm 0.6$ & $96.9 \pm 0.6$ \\
\hline Day 30 & $95.9 \pm 1.9$ & $100.7 \pm 0.7$ & $97.0 \pm 1.3$ \\
\hline
\end{tabular}

$\mathrm{SD}=$ standard deviation.

*Except as indicated otherwise.

tMean \pm SD $(n=6)$.

$\neq$ With protection from light.

$\S$ With exposure to light. 
Ciprofloxacin has reported pKa values of 6.09 and 8.62. Therefore, at $\mathrm{pH}$ above 6.0, some of the insoluble base would be expected to precipitate, and in preliminary studies, an increase in $\mathrm{pH}$ above 6 did cause the ciprofloxacin to precipitate. Teraoka and others ${ }^{3}$ reported a similar finding, a substantial decrease in ciprofloxacin concentration when the $\mathrm{pH}$ of the admixtures rose above 6 . Even though the $\mathrm{pH}$ was adjusted upward to only 5 for the alkaline degradation sample, heating of this sample caused the largest decrease in ciprofloxacin concentration during the degradation studies.

The slight increase in concentration at day 30 with storage at the highest temperature $\left(29^{\circ} \mathrm{C}\right.$ to $\left.31^{\circ} \mathrm{C}\right)$ might have been due to evaporation from the bags. The manufacturer of the prefilled bags recommends that the product not be used beyond 14 days at $25^{\circ} \mathrm{C}$ once the overwrap has been removed (Hospira Clinical Support Team, Hospira Healthcare Corp, Saint-Laurent, Quebec; personal communication by letter, June 9, 2011).

\section{CONCLUSIONS}

Ciprofloxacin admixtures prepared by dilution of the commercial $10 \mathrm{mg} / \mathrm{mL}$ solution with either D5W or NS were stable in PVC bags for up to 30 days when stored at $2^{\circ} \mathrm{C}$ to $8^{\circ} \mathrm{C}$ with protection from light, at $21^{\circ} \mathrm{C}$ to $24^{\circ} \mathrm{C}$ with exposure to light, or at $29^{\circ} \mathrm{C}$ to $31^{\circ} \mathrm{C}$ with protection from light. This longer expiry date, which is based on physical and chemical stability, will allow for commercially available ciprofloxacin concentrate (in vials) to be diluted in minibags, which will reduce wastage when usage volumes are low. Alternatively, the longer expiry date will allow preparation of ciprofloxacin in NS minibags when D5W cannot be used for clinical reasons. The final expiry date should also be based on individual institutions' aseptic compounding policy.

\section{References}

1. Bing CM. Extended stability for parenteral drugs. 2nd ed. Bethesda (MD): American Society of Health-System Pharmacists; 2003.

2. Tiefenbacher EM, Haen E, Pryzbilla B, Kurz H. Photodegradation of some quinolones used in antimicrobial therapeutics. J Pharm Sci 1994;83(4): 463-467.

3. Teraoka K, Minakuchi K, Tsuchiya K, Takasugi M. Compatibility of ciprofloxacin infusion with other injections. Jpn J Hosp Pharm 1995; 21(6):541-550.

4. Faouzi MA, Dine T, Luyckx M, Goudaliez F, Mallevais ML, Brunet C, et al. Stability and compatibility studies of pefloxacin, ofloxacin and ciprofloxacin with PVC infusion bags. Int J Pharm 1993;89:125-131.

5. USP-NF Online [USP 30-NF 25]. Rockville (MD): US Pharmacopeia; [cited 2007 Aug 14]. Available from: www.uspnf.com/uspnf/login. Subscription required to access content.

6. Mathew M, Das Gupta V, Zerai T. Stability of ciprofloxacin in 5\% dextrose and normal saline injections. J Clin Pharm Ther 1994;19(4):261-262.

7. Cipro product monograph. Boucherville (QC): Sandoz Canada Inc; 2006 Feb 28.
Ronald F Donnelly, MSc(Chem), BSc(Pharm), is Product Development Pharmacist with the Department of Pharmaceutical Sciences, The Ottawa Hospital (Civic Campus), Ottawa, Ontario.

\section{Address correspondence to: \\ Ronald F Donnelly \\ Department of Pharmaceutical Sciences \\ The Ottawa Hospital \\ 1053 Carling Avenue \\ Ottawa ON K1Y 4E9 \\ e-mail: rdonnelly@ottawahospital.on.ca}

\section{Acknowledgement}

Sandoz Canada provided an unrestricted research grant for this project. The company was not involved in the conduct of the study; the collection, management, or interpretation of the data; or the preparation, review, or approval of the manuscript. 